\title{
Analisis Kelas Virtual Google Classroom Pada Pelatihan TIK Bagi Guru Madrasah Tsanawiyah Di Wilayah Kerja Kantor Kementerian Agama Kabupaten Labuhan Batu Selatan
}

Balai Diklat Keagamaan Medan JI. TB. Simatupang No. 122 Medan Telp. (061)8456256

E-mail: narnowibdkmdn@gmail.com Naskah diterima: 24 April 2021

Naskah Direvisi: 30 April 2021

Naskah disetujui: 10 Mei 2021 Website Jurnal: http://apicbdkmedan.kemenag.go.id.

\section{Gunarno}

\begin{abstract}
ABSTRAK
Analisis Kelas Virtual Google Classroom Pada Pelatihan Teknologi Informasi dan Komunikasi pada Pelatihan TIK Bagi Guru Madrasah Tsanawiyah di wilayah Kerja Kementerian Agama Kabupaten Labuhan Batu Selatan. Penelitian ini bertujuan untuk mengetahui gambaran kelas virtual google classroom yang telah dibuat oleh guru peserta pelatihan pada Pelatihan TIK Bagi Guru Madrasah Tsanawiyah di Wilayah Kerja Kementerian Agama Kabupaten Labuhan Batu Selatan. Subjek penelitian adalah peserta Pelatihan TIK Bagi Guru Madrasah Tsanawiyah di Wilayah Kerja Kementerian Agama Kabupaten Labuhan Batu Selatan yang diselenggarakan pada tanggal 11 s.d. 16 Januari 2021 berjumlah 30 orang, dengan 2 aspek yang diamati yaitu aspek umum dan aspek aksesibelitas. Metode penelitian ini adalah penelitian deskriptif. Data diperoleh melalui observasi kemudian dianalisis menggunakan analisis rerata. Hasil analisis data menunjukkan bahwa 46,67\% peserta diklat memiliki nilai kelayakan kelas virtual Google Classroom dengan kategori "Sangat Layak", 53,33\% peserta diklat memiliki nilai kelayakan dengan kategori "Layak".
\end{abstract}

Kata Kunci: kelas virtual, google classroom, guru, MTs.

\section{ABSTRACT}

Google Classroom Virtual Class Analysis on Information and Communication Technology (ICT) Training for Madrasah Tsanawiyah Teachers in the Work Area of the Ministry of Religion, South Labuhan Batu Regency. This study aims to determine the description of the virtual google classroom that has been created by the trainee teachers in ICT Training for Madrasah Tsanawiyah Teachers in the Work Area of the Ministry of Religion, Labuhan Batu Selatan Regency. The research subjects were participants in the ICT Training for Madrasah Tsanawiyah Teachers in the Work Area of the Ministry of Religion, Labuhan Batu Selatan Regency, which was held from 11 until 16 January 2021 totaled 30 people, with 2 aspects observed, namely the general aspect and the accessibility aspect. This research method is descriptive research. Data was obtained through observation and then analyzed using mean analysis. The results of data analysis showed that $46.67 \%$ of the training participants had an eligibility value of the Google Classroom virtual class with the "Very Eligible" category, 53.33\% of the training participants had a feasibility value in the "Eligible" category.

Keywords: virtual classroom, google classroom, teacher, MTs. 


\section{PENDAHULUAN}

Setahun lebih pandemi COVID-19 melanda negara-negara diseluruh dunia, tidak terkecuali Indonesia. Pandemi memiliki dampak sekunder yang sangat luas terhadap 80 juta anak Indonesia dan kehidupan sehari-hari mereka. Pendidikan jutaan anak dan remaja terganggu (UNICEF, 2021). Penutupan sementara Lembaga Pendidikan sebagai upaya menahan penyebaran pandemic covid-19 di seluruh dunia berdampak pada jutaan pelajar, tidak tekecuali di Indonesia. Gangguan dalam proses belajar langsung antara

Dewasa ini sebagai bentuk imbas dan respon positif terkait perkembangan teknologi, pemerintah juga menggencarkan Kurikulum 2013 meskipun kurikulum terus mengalami perubahan seiring perkembangan teknologi. Sebagai respon positif itulah pemerintah memberikan fasilitas berupa buku guru maupun buku siswa yang mudah diakses secara online oleh guruguru maupun siswa. Selain kemudahan dalam mengakses bahan ajar, guru-guru juga dituntut untuk lebih inovatif dan kreatif terutama menyikapi kebijakan dalam menerapkan pembelajaran berbasis komputer yaitu dengan cara guru melek teknologi.

Untuk menunjang pengembangan pembelajaran yang lebih baik dan menarik, para guru diarahkan untuk memaksimalkan pemanfaatan teknologi informasi dan aplikasi komputer berbasis multimedia. Pemanfaatan teknologi informasi khususnya internet bertujuan untuk memperkaya konten materi yang akan disampaikan, sedangkan aplikasi presentasi dan multimedia digunakan untuk mengemas konten yang disiapkan menjadi kesatuan media pembelajaran yang menarik dan berkualitas.

Guru menyediakan pengalaman belajar bagi peserta didik untuk melakukan berbagai kegiatan yang memungkinkan mereka mengembangkan potensi yang mereka miliki. Inilah sebabnya pembuatan kelas virtual untuk pembelajaran daring penting untuk dilakukan oleh guru.

Kurikulum 2006 dikembangkan menjadi Kurikulum 2013 dengan dilandasi pemikiran tantangan masa depan yaitu tantangan abad ke-21 yang ditandai dengan abad ilmu pengetahuan, know/wdge-based society dan kompetensi masa depan. Agar pelaksanaan Kurikulum 2013 dapat berjalan dengan baik, perlu dilakukan pelatihan Teknologi Informasi dan Komunikasi (TIK) bagi para guru Madrasah Tsanawiyah di lingkungan Kementerian Agama Kabupaten Labuhan Batu Selatan yang dilaksanakan tanggal 11 s.d. 16 Januari 2021. Salah satu tujuan dari pelatihan TIK adalah agar guru dapat memahami dan mampu memanfaatkan membuat kelas virtual pada platform Google Classroom. Dengan adanya TIK sebagai media dan sumber pembelajaran dalam pendidikan dapat memajukan kualitas pembelajaran.

Berdasarkan uraian diatas peneliti melakukan penelitian dengan judul "Analisis Kelas Virtual Google Classroom Pada Peserta Pelatihan TIK Bagi Guru Madrasah Tsanawiyah di Wilayah 
Kerja Kementerian Agama Kabupaten Labuhan Batu Selatan. Rumusan masalah yang akan dijawab dalam penelitian ini adalah: Bagaimanakah kelas virtual google classroom yang dibuat oleh peserta Pelatihan TIK Bagi Guru Madrasah Tsanawiyah di Wilayah Kerja Kementerian Agama Kabupaten Labuhan Batu Selatan? Tujuan dari penelitian ini adalah untuk mendapatkan gambaran kelas virtual google classroom yang telah dibuat oleh peserta Pelatihan TIK Bagi Guru Madrasah Tsanawiyah di Wilayah Kerja Kementerian Agama Kabupaten Labuhan Batu Selatan.

Manfaat dari penelitian ini adalah sebagai berikut: 1) sebagai bahan refleksi sekaligus masukan bagi guru dalam pembuatan kelas virtual; 2) sebagai bahan masukan bagi pengawas pada saat membimbing guru dalam pembuatan kelas virtual; 3) sebagai bahan evaluasi bagi Balai Diklat Keagamaan Medan terhadap hasil pelaksanaan Pelatihan TIK bagi guru madrasah.

Pandemi corona COVID-19 nyaris melumpuhkan semua negara, tidak terkecuali Indonesia. Kegiatan social, ekonomi, sosial, tidak terkecuali Indonesia. Saat ini negara kita sedang memberlakukan peringatan dan pelarangan untuk keluar, bekerja maupun bersekolah. Sehingga memunculkan banyak istilah seperti work from home atau belajar dari rumah.

Tentunya bagi siswa, peraturan ini akan mengganggu proses belajar mereka terlebih lagi saat ini banyak siswa berada di tahun terakhir sekolah mereka lebih membutuhkan waktu belajar yang lebih banyak untuk menghadapi ujian akhir.
Tetapi pemerintah Indonesia telah mengeluarkan pengumuman peniadaan ujian nasional untuk tetap meminta masyarakat tetap berada dirumah dan memutus serta memperpendek rantai penyebaran corona.

Meskipun begitu, siswa juga harus tetap belajar walau melalui cara online. Para guru dan dosen dituntut menjadi kreatif untuk tetap meraih dan mengajar siswa- siswa mereka. Cara mengajar yang paling aman untuk saat ini adalah tentunya melalui aplikasi seperti google classroom. Jika Anda seorang siswa atau seorang guru yang masih mencari platform untuk saling belajar dan berkomunikasi, mari simak dan mengenal apa itu google classroom.

Kegiatan pembelajaran tidak hanya merupakan proses interaksi antara guru dan siswa. Salah satu diantaranya yaitu adanya interaksi antara media yang di gunakan guru dengan siswa. Media diartikan sebagai pengantar atau perantara, yaitu sebagai pengantar pesan dari pengirim kepada penerima (Suprihatingrum, 2013:319). Dapat dikatakan bahwa media merupakan alat dan bahan yang berisi informasi atau bahan pelajaran yang bertujuan untuk mempermudah mencapai tujuan pembelajaran.

Menurut Sadiman, dkk (2009:1-2) belajar tidak selamanya bersentuhan dengan hal-hal yang konkrit, baik dalam konsep maupun faktanya. Bahkan dalam realitasnya, belajar seringkali bersentuhan dengan hal-hal yang bersifat kompleks, maya dan berada di balik fakta. Oleh karena itu, media berperang menjelaskan 
hal-hal yang abstrak dan menunjukkan hal-hal yang tersembunyi. Ketidakjelasan atau kerumitan bahan ajar dapat dibantu dengan menghadirkan media sebagai perantara. Bahkan dalam hal-hal tertentu, media dapat mewakili kekurangan guru dalam mengkomunikasikan materi pelajaran. Namun perlu diingat bahwa peranan media tidak akan terlihat apabila penggunaanya tidak sejalan dengan esensi tujuan pengajaran yang telah dirumuskan. Oleh karena itu, tujuan pembelajaran harus dijadikan sebagai pangkal acuan untuk menggunakan media. Manakala diabaikan, melainkan sebagai penghambat dalam pencapaian tujuan secara efektif dan efisien.

Menurut Sadiman, dkk (2009:14) penggunaan media pembelajaran dalam proses belajar-mengajar sangat penting diterapkan oleh guru di sekolah, namun lebih penting peran guru sebagai agen pembelajaran, karena guru adalah penggerak utama yang memfasilitasi proses belajar mengajar di kelas". Oleh karena itu, guru tidak dibenarkan menghindar dari kewajibannya sebagai pengajar dan pendidik untuk tampil dihadapan anak didik dengan seluruh kepribadiannya.

Dalam proses belajar-mengajar ada banyak faktor yang mempengaruhi tercapainya tujuan pembelajaran, antara lain faktor guru sebagai pendidik anakanak sebagai peserta didik, lingkungan metode dan teknik serta media pembelajaran.

Pada kenyataannya "apa yang terjadi dalam pembelajaran seringkali terjadi proses pengajaran berjalan dan berlangsung tidak efektif, banyak waktu, tenaga dan biaya yang terbuang sia-sia sedangkan tujuan belajar tidak dapat tercapai bahkan terjadi miskomunikasi Antara pengajar dan pelajar." Hal tersebut masih sering dijumpai pada proses pembelajaran selama ini (Sadiman, dkk 2009:10)

Menurut Aunurrahman (2009:139) keberhasilan penggunaan media pembelajaran dalam proses belajarmengajar tidak terlepas dari kemamouan guru mengembangkan model-model pembelajaran yang berorientasi pada peningkatan intensitas keterlibatan anak secara efektif didalam proses pembelajaran. Pengembangan model pembelajaran yang tepat pada dasarnya bertujuan untuk menciptakan kondisi pembelajaran yang meungkinkan peserta didik dapat meraih hasil belajar dan prestasi yang optimal.

\section{Aunurrahman}

(2009:140) mengemukakan bahwa "untuk dapat menggunakan media pembelajaran dalam proses belajar-mengajar secara lebih efektif, maka guru harus memiliki pengetahuan yang memadai berkenaan dengan konsep dan cara mempraktekkan model-model media pembelajaran yang ada". Penggunaan media pembelajaran dalam proses belajar-mengajar hendaknya berdasarkan pada tujuan dan aspek per kembangan anak serta sesuai dengan materi pembelajaran dan sesuai dengan karakteristikanak sehingga guru mudah menyampaikan pelajaran dengan baik pada anak.

Hamalik (dalam Arsyad 2002:15) menyatakan bahwa "penggunan media 
pembelajaran dalam proses belajarmengajar dapat mengungkit keinginan dan minat yang baru, membangkitkan motivasi dan rangsangan kegiatan belajar, dan bahkan membawa pengaruhpengaruh psikologi terhadap anak".

\section{METODOLOGI PENELITIAN}

Berdasarkan pada permasalahan yang diajukan dalam penelitian ini, maka jenis penelitian yang relevan dengan penelitian ini adalah penelitian deskriptif. Penelitian deskriptif adalah penelitian yang menghasilkan data yang dapat diamati serta memberikan gejala-gejala, fakta-fakta atau kejadian secara sistematis dan akurat untuk memberikan gambaran lebih jauh tentang apa yang menjadi obyek penelitian (Sugiyono, 2008).

Penelitian ini diharapkan dapat memberikan berbagai informasi kualitatif dengan deskripsi analisis yang teliti dan penuh makna, yang juga tidak menolak informasi kuantitatif dalam bentuk angka maupun jumlah. Pada tiap-tiap obyek akan dilihat kecenderungan, pola pikir, ketidakteraturan, serta tampilan perilaku dan integrasinya.

Sumber data didalam penelitian ini adalah google classroom yang telah disusun oleh peserta Pelatihan TIK Bagi Guru Madrasah Tsanawiyah di Wilayah Kerja Kementerian Agama Kabupaten Labuhan Batu Selatan yang dilaksanakan tanggal 11 s.d. 16 Januari 2021. Teknik pengumpulan data dalam penelitian ini adalah observasi terhadap 30 google classroom yang telah disusun oleh 30 orang peserta diklat.

Instrumen penelitian ini untuk mengamati dan mencatat langsung paparan guru pada saat proses presentasi hasil produk kelas virtual google classroom yang dibuat masing-masing peserta. Peneliti melaksanakan observasi dengan memberikan tanda checklist $(\sqrt{ })$ pada kolom yang tersedia pada lembar observasi sesuai dengan keadaan sebenarnya. Observasi digunakan untuk mengetahui kelayakan kelas virtual google classroom yang dibuat oleh pesera diklat yang meliputi aspek umum dan aspek aksesibilitas.

Dalam penelitian ini jawaban butir instrumen diklasifikasikan menjadi lima pilihan. Setiap indikator yang diukur diberikan skor skala 1-5, yaitu 5 (sangat layak), 4 (layak), 3 (kurang layak), 2 (tidak layak), dan 1 (sangat tidak layak). Selanjutnya menentukan tingkat kelayakan kelas virtual google clasroom dapat dihitung dengan rumus sebagai berikut:

Hasil $=\frac{\text { total skor yang diperoleh }}{\text { skor maksimum }} \times 100 \%$

Kategori kelayakan berdasarkan kriteria sebagai berikut (Arikunto, 2009).

Tabel 1. Kategori Kelayakan Kelas Virtual Google Classroom

\begin{tabular}{ccc}
\hline No. & Skor (\%) & Kategori Kelayakan \\
\hline 1 & $81-100$ & Sangat Layak \\
\hline 2 & $61-80$ & Layak \\
\hline 3 & $41-60$ & Cukup Layak \\
\hline 4 & $21-40$ & Tidak Layak \\
\hline 5 & $<21$ & Sangat Tidak Layak \\
\hline
\end{tabular}




\section{HASIL DAN PEMBAHASAN}

Data dalam penelitian ini diperoleh dari pengisian instrumen berupa lembar observasi yang diisi oleh peneliti untuk menilai hasil kelayakan dari kelas virtual google classroom yang dikembangkan oleh peserta pelatihan.
Berdasarkan hasil analisis terhadap 30 kelas virtual google classroom yang telah dibuat oleh peserta pada Pelatihan TIK Bagi Guru Madrasah Tsanawiyah di Wilayah Kerja Kementerian Agama Kabupaten Labuhan Batu Selatan adalah sebagai berikut:

Tabel 2. Hasil Kelayakan Kelas Virtual Google Classroom

\begin{tabular}{lccc}
\hline \hline No. & Komponen & $\begin{array}{c}\text { Rata-rata Nilai } \\
\text { (\%) }\end{array}$ & Kategori \\
\hline \hline 1. & Aspek Umum & 77,87 & Layak \\
\hline 2. & Aksesibilitas & 85,23 & Layak \\
\hline
\end{tabular}

Presentase kelayakan kelas virtual google classroom ditinjau dari aspek umum yaitu memperoleh nilai rata-rata 77,87\%. Berdasarkan aspek aksesibilitas memperoleh data rata-rata $85,23 \%$. Adapun total presentase dari keseluruhan aspek yang diperoleh adalah 81,55\%, sehingga secara keseluruhan kelas virtual google classroom dikategorikan "sangat layak" untuk digunakan. Nilai kelayakan kelas virtual google classroom tersebut dapat dilihat pada gambar 1 berikut.

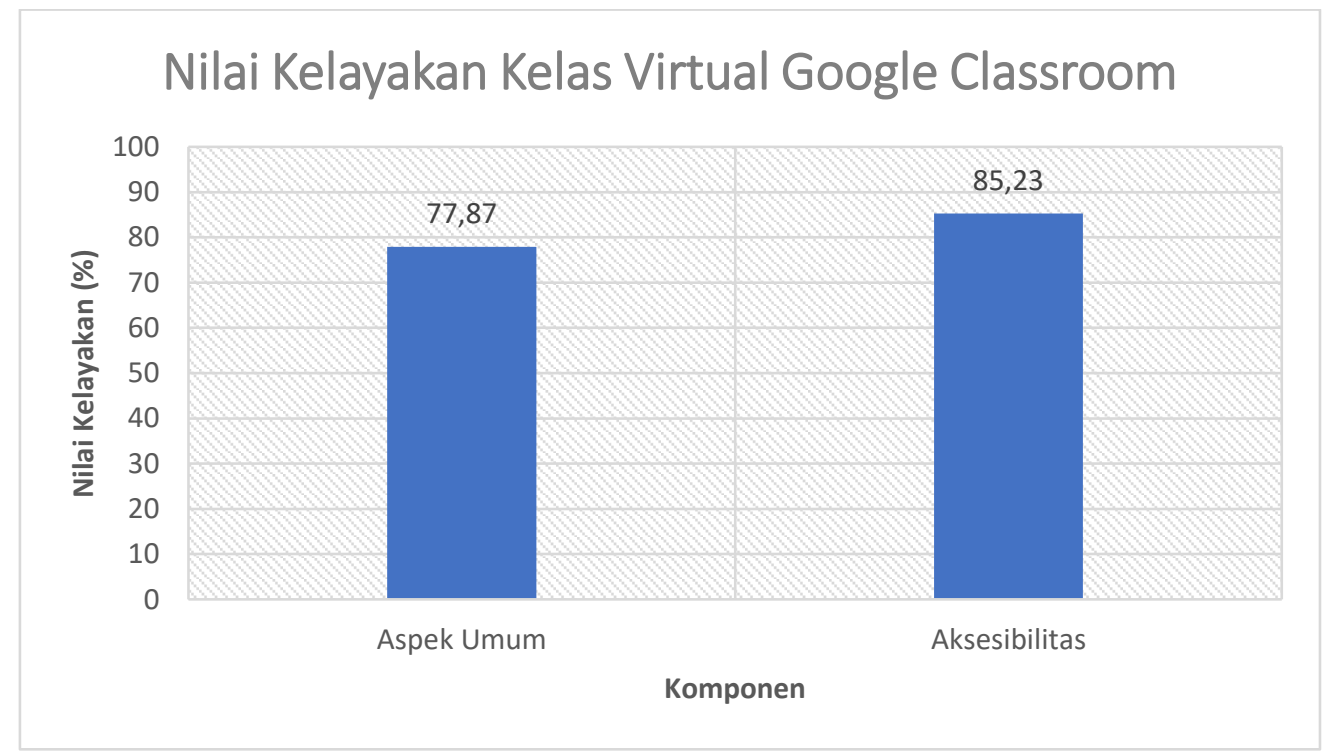

Gambar 1. Diagram Nilai Kelayakan Kelas Virtual Google Classroom

Menurut diagram diatas, komponen google classroom hampir kemampuan peserta diklat pada setiap sama, yaitu masuk kategori "sangat 
layak". Peserta diklat rata-rata memilliki kemampuan dasar yang sangat kuat tentang kelas virtual, hanya sebagian kecil peserta yang memiliki kemampuan dasar sedang tentang kelas virtual, bahkan tidak ada peserta diklat dengan kemampuan dasar yang rendah. Hal ini mungkin disebabkan sebagian besar peserta berpendidikan Strata 1 (S-1) dan memiliki usia yang muda. Dari penelitian ini juga diketahui persentase jumlah peserta diklat menurut kategori kelayakan kelas virtual google classroom yang dibuat oleh 30 peserta diklat pada Pelatihan TIK Bagi Guru Madrasah Tsanawiyah di wilayah kerja Kementerian Agama Kabupaten Labuhan Batu Selatan. Adapun persentase jumlah guru menurut kategori kelayakan tersebut disajikan pada tabel 2.

Tabel 3. Presentase Jumlah Peserta Pelatihan Menurut Kategori Kelayakan

\begin{tabular}{lcccccc}
\hline No & Komponen Kelas & \multicolumn{5}{c}{ Kategori Kelayakan } \\
\cline { 3 - 7 } & Virtual & SL & L & CL & TL & STL \\
& & $(\%)$ & $(\%)$ & $(\%)$ & $(\%)$ & $(\%)$ \\
& & & & & - & - \\
\hline 1 & Aspek Umum & 46,67 & 53,33 & - & - & - \\
\hline 2 & Aksesibilitas & 66,67 & 33,33 & - & - \\
\hline
\end{tabular}

Komponen kelas virtual google classroom untuk aspek umum hasil penelitian menunjukkan bahwa dari 30 orang peserta diklat, sebanyak 14 orang $(46,67 \%)$ memiliki nilai kelayakan yang masuk kategori "sangat layak". Sedangkan 16 orang (53,33\%) memiliki nilai kelayakan yang masuk kategori "layak". Untuk komponen kelas virtual google classroom pada aksesibilitas hasil penelitian menunjukkan bahwa dari keseluruhan peserta diklat, 20 orang $(66,67 \%)$ memiliki nilai kelayakan dengan kategori "sangat layak", dan 10 orang $(33,33 \%)$ memiliki nilai kelayakan dengan kategori "layak". Persentase jumlah guru menurut nilai kelayakan kelas virtualnya dapat dilihat pada gambar 2 berikut. 


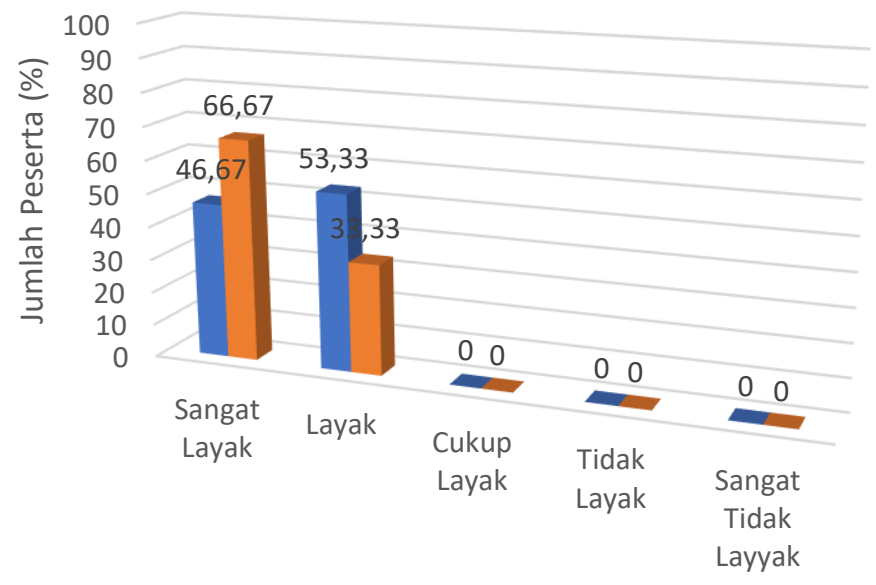

- Aspek Umum

Aksesibilitas

Kelayakan

Gambar 2. Diagram Jumlah Peserta Diklat Menurut Nilai Kelayakan Kelas Virtual Google Classroom

$\begin{array}{ll}\begin{array}{l}\text { Diagram diatas menunjukkan } \\ \text { bahwa jumlah peserta diklat dengan }\end{array} & \begin{array}{l}\text { seluruh komponen menunjukkan bahwa: } \\ \text { kategori "sangat layak" dan "layak" pada }\end{array} \\ \text { memiliki nilai kelayakan dengan kategori } \\ \text { komponen kelas virtual google classroom } & \text { "Sangat Layak" dan } 16 \text { orang peserta } \\ \text { "Aspek umum". Demikian halnya untuk } & \text { diklat (53,33\%) memiliki nilai kelayakan } \\ \text { komponen kelas virtual google classroom } & \text { dengan kategori "Layak". Data } \\ \text { "Aksesibilitas". Data penelitian juga } & \text { persentase tersebut dapat diamati pada } \\ \text { menunjukkan bahwa nilai kelayakan } & \text { gambar 3, berikut: }\end{array}$

kelas virtual google classroom dari

\section{Kategori Kelayakan Kelas Virtual Google Classroom}

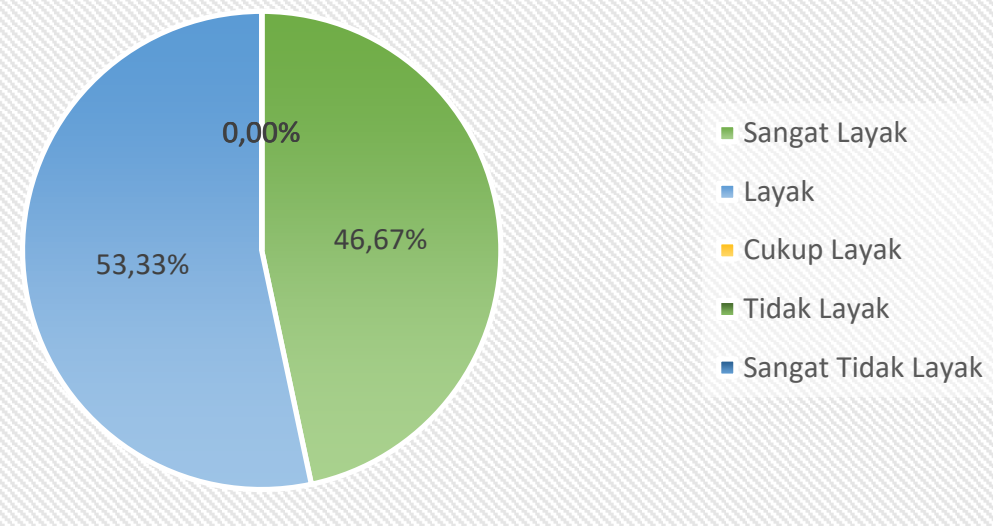

Gambar 3. Diagram Jumlah Guru Menurut Nilai Kelayakan Kelas Virtual Google Classroom 


\section{SIMPULAN}

Berdasarkan pembahasan hasil penelitian tersebut, maka dapat disimpulkan bahwa presentase kelayakan kelas virtual google classroom ditinjau dari aspek umum $77,87 \%$ dan aspek aksesibilitas 85,23\%. Secara keseluruhan secara keseluruhan kelas virtual google classroom adalah 81,55\% dikategorikan "sangat layak" untuk digunakan. Jumlah peserta berdasarkan nilai kelayakan pada aspek umum menunjukkan sebanyak 14 orang $(46,67 \%)$ masuk kategori "sangat layak" dan 16 orang $(53,33 \%)$ masuk kategori "layak". Jumlah peserta berdasarkan nilai kelayakan pada aspek aksesibilitas menunjukkan 20 orang $(66,67 \%)$ memiliki nilai kelayakan dengan kategori "sangat layak" dan 10 orang (33,33\%) masuk kategori "layak". Hasil penelitian juga menunjukkan bahwa berdasarkan keseluruhan komponen terdapat $46,67 \%$ peserta diklat memiliki nilai kelayakan kelas virtual google classroom dengan kategori "Sangat Layak" dan 53,33\% peserta diklat memiliki nilai kelayakan dengan kategori "Layak".

\section{SARAN}

Berdasarkan simpulan tersebut, maka dapat disarankan sebagai berikut:
1) peserta diklat perlu mengembangkan kemampuan tentang pembuatan kelas virtual pada platform google classroom; 2) peserta diklat hendaknya mengaplikasikan produk kelas virtual google classroom dalam setiap proses kegiatan belajar mengajar daring; 3) mengoptimalkan kegiatan MGMP untuk meningkatkkan kemampuan peserta diklat dalam membuat kelas virtual google classroom sebagai kelas daring.

\section{DAFTAR PUSTAKA}

Arsyad (2002). "Karakteristik Media Pembelajaran".Jakarta PT Raja Garfindo Persada.

Aunurrahman. 2009. Belajar dan Pembelajaran. Bandung: Alfabeta.

Arikunto, Suharsimi. 2006. Prosedur Penelitian Suatu Pendekatan Praktik. Jakarta: PT Rhineka Cipta.

Sadiman, dkk. 2009. Media Pendidikan, Pengertian, Pengembangan, dan Pemanfaatannya. Jakarta: Rajawali Press.

Sugiyono. 2008. Metode Penelitian Pendidikan (Pendekatan Kuantitatif, Kualitatif, dan R\&D). Bandung: Alfabeta.

Suprihatiningrum. $2013 . \quad$ Strategi Pembelajaran Teori \& Aplikasi. Jogjakarta: Ar-Ruzz Media

UNICEF, 2021, Menuju respons dan pemulihan COVID-19 yang berfokus pada anak: Seruan aksi. Jakarta. 